Article

\title{
Fare Evasion and Ticket Forgery in Public Transport: Insights from Germany, Austria and Switzerland
}

\author{
Elmar Wilhelm M. Fürst ${ }^{1}$ and David M. Herold ${ }^{2, *}$ \\ 1 Institute for Transport and Logistics Management, WU (Vienna University of Economics and Business), \\ Welthandelsplatz 1, 1020 Vienna, Austria; elmar.fuerst@wu.ac.at \\ 2 Department of International Business and Asian Studies, Griffith University, Gold Coast Campus, \\ Parkland Drive, 4215 Southport, Australia \\ * Correspondence: d.herold@griffith.edu.au
}

Received: 12 September 2018; Accepted: 3 October 2018; Published: 8 October 2018

\begin{abstract}
Local public transport companies provide important mobility services to the general public. Although these services are usually subsidised, companies rely on revenues generated by ticket sales. Therefore, fare evasion (i.e., people using a transport service without paying for it) and ticket forgery (the production of an illegal ticket facsimile) have considerable influence on the companies' economic sustainability. As existing research regarding the economic perspective is limited, this paper presents a Delphi study that investigates the phenomena with a survey of experts in public transport companies and transport associations in Germany, Austria, and Switzerland. The findings of the survey provide insights into the overall perception and discuss relevant aspects of both fare evasion and ticket forgery, thereby not only highlighting practical implications, but also helping policy makers shape adequate policies for public transport in societies.
\end{abstract}

Keywords: fare evasion; ticket forgery; local public transport; Delphi analysis; economic sustainability

\section{Introduction}

Public transport companies are the backbone of urban transport networks and provide important mobility services to the general public. As these services are of great importance to the vast majority of people, provincial and state governments are normally responsible for financing infrastructure networks and-at least in part-for the maintenance of the services. However, the use of public transport services is usually not free of charge for passengers. Although tariffs are frequently subsidised, revenues generated by ticket sales are an important source of income for transport companies and make a significant contribution to keeping the system financially viable [1-4]. The problems of fare evasion (free-riding, fare dodging or toll fraud; i.e., people using a transport service without paying for it) and ticket forgery (ticket fraud, ticket falsification; i.e., the production of an illegal ticket facsimile) are, of course, not new to transport industries [5,6]. Due to technological advances (on the part of suppliers as well as the passengers), these phenomena seem to be developing as well $[2,7]$.

Different approaches to ticket control, electronic ticketing, a rise in propensity to violence, an increase in poverty or better copying machines are but a few of the impact factors which render the problem more and more serious and thereby threaten transport companies' economic sustainability [8,9]. While passengers are, in general, rather insensitive to changes in prices or payment systems and much more sensitive to changes in travel time and service improvements [10], the losses caused by fare dodging and ticket fraud are substantial [3]. Thus, transport companies need to react to recent developments if they want to avoid a considerable loss of income at present and in the future [4]. 
From an academic viewpoint, most research on transit fare evasion and ticket forgery focuses on how system design and engineering factors can reduce fare evasion and focus either on the impact of physical control methods (e.g., ticket gates vs. proof-of-payment) or the influence of control processes such as inspection rates and fines [11,12]. Early studies investigated the impact of upgrading ticket control systems on fare evasion rates in metro systems [13-15]. The focus of these early studies was on documenting the benefits of newly available technologies, such as improved ticketing systems and upgraded ticket barriers. More recently, a series of studies have examined the impacts of reducing the amount of physical control over ticketing, examining the trade-off between the potential costs (revenue lost from fare evasion, increased salaries for ticket inspections) and benefits (speed and reliability improvements, reduced stop dwell time, increased ridership, lower vehicle operational and purchase costs) $[16,17]$ as well fare evader behaviour $[18,19]$. Theoretical modelling to address fare evasion and ticket forgery is quite popular, usually using econometric approaches or game-theory [20-22], however these studies often focus on mathematically estimating the optimal inspection rate or patrol location to reduce fare evasion or maximise profit [23-25].

However, despite this growing literature examining public transport fare evasion and fraud, research with practical relevance is limited. In response, this paper presents an overview and a discussion of the relevant aspects of both free-riding and ticket fraud by means of a three-round Delphi expert-based survey in Germany, Austria and Switzerland, respectively. Based on the opinion of the experts, our research examines the overall perception of the phenomena, their development over time, passengers' motives, measures and technologies to prevent and combat fare evasion and ticket forgery, penalties, estimated revenue losses, related legal regulations, social aspects of ticket checking procedures, the acceptance of inspections by paying passengers and whether using a transport service without paying is seen only as a trivial offence or rather as a serious delict. The contribution of the paper is two-fold: First, the survey advances the body of knowledge in the area of public transport by presenting comprehensive and coherent findings with respect to fare evasion and forgery. Existing literature to date has not sufficiently distinguished between these two issues or used extensive modeling to investigate the phenomena, thereby lacking practical relevance. Second, the findings give not only insights into the characteristics and drivers of fare evasion and ticket forgery, but discuss the practical implications for Germany, Austria and Switzerland, thereby helping policy makers to shape the right policies for public transport in societies.

The remainder of paper is organised as follows. First, free-riding and ticket fraud are discussed in the context of financial sustainability. This is followed by the methods section presenting the Delphi process to investigate and analyse these phenomena. The subsequent section represents the core section of the paper and presents and discusses the findings of the Delphi survey in detail. The paper concludes by highlighting implications with practical relevance as well as an outlook for further research.

\section{Fare Evasion and Ticket Forgery as Threats to the Financial Sustainability}

Whereas ticket forgery is generally regarded as a serious crime, a surprising number of people see free-riding as a relatively trivial offence. Yet, both result in a substantial loss of income for local public transport service providers [3]. Nevertheless, ticket forgery is driven by large-scale gain while the core motive for free-riding tends to be of an individual nature. Indeed, there are also cases where a transport user forgets to buy or validate a ticket, or the holder of a ticket mistakes its validity (regarding period or area of validity or other ticket conditions) and uses it falsely, unintentionally becoming a free-rider. A deliberate free-rider, in contrast, decides not to pay for a service in order to save the fare-usually calculating the risk of being detected and fined-thereby obtaining a personal benefit. The majority of free-riders, therefore, are focused on their personal advantage and do not involve others in their actions. This is even the case for "professional" fare-dodgers, who generally refrain from buying tickets or weigh the sum of ticket prices for a particular period of time against the sum of fines probably payable during that period, thus maximising their expected utility [26]. Other reasons may also include psychological motives (e.g., the thrill of not being caught, to fool staff or to exploit the 
state). Finally, it is important to note that not all free-riders are equal. There is evidence that personal characteristics as well as the passenger's company have a significant influence on whether somebody holds a valid ticket or not $[27,28]$.

In contrast, ticket forgery principally involves a higher degree of criminal intent and energy. It not only implies the omission of a payment ("non-action") but the dedicated investment of time and effort. In fact, the severity can vary, depending on the actual circumstances of the case (e.g., a ticket regularly bought is used twice if, for instance, the imprinter's stamp for the first ride was too light and thus the second stamp conceals the first one, compared with a criminal organisation breaking into ticket machines and stealing rolls of original ticket paper in order to commit professional forgery). Technologies employed by specialised criminal groups are sometimes very sophisticated and thus the detection of these crimes is not easy. According to unofficial reports of company representatives, some attempts have only been revealed because of a typing error in the advertisement on the reverse side of the ticket or because of unvaried serial numbers. Thus, there is practically no qualitative information on ticket forgery-understandably a very sensitive topic for transport companies-and statistical data is generally not available. However, a clear aggravation can be noticed as the mere resale of used tickets persists and professionals trade manipulated or forged tickets more frequently [29,30]. Major crimes are still rare, but do exist. Recently, Italian customs and police seized a container arriving from China to discover 28 million Euros' worth of forged tickets from Rome's Central Station to the capital's airport, Fiumiciono [31].

Unfortunately, few statistics about the actual development of fare evasion and ticket forgery are publicly available [6,15], in particular in a German, Austrian or Swiss context. It also seems that there is no 'general trend' but rather a strong connection between a city's individual parameters and the attempts and approaches of local public transport companies to deter fare evasion. Very few figures can be found on fare controls and the resulting free-riding quota. Thus, only some spotlights can be presented here.

For Vienna, the municipal public transport company Wiener Linien has provided figures showing a downward tendency in the rate of detected free-riders, from $4.55 \%$ in 2004 to $3.04 \%$ in the first few months of 2010 [32]. In the period from January to March 2012, the rate was down to $2.96 \%$. However, ticket controls have almost doubled since 2005, showing that this reduction comes at a cost. Effective from May 2012, a substantial reform of ticket prices was implemented and the penalty fee for not being able to present a valid ticket rose from 70 to 100 Euros [33].

According to a survey conducted by the journal WirtschaftsWoche, the situation in Germany is quite similar (Table 1). The free-rider rate ranges from 0.6 to $6.0 \%$. The income loss for the 35 largest cities' public transport companies amounts to $€ 120$ million (regardless of the costs for controls). According to estimates by the Association of German Transport Companies (VDV), the income loss in Germany could be as high as $€ 350$ million per year [34]. For Italy, a loss of around $€ 450$ million has been estimated; however, it seems likely that there is also a substantial number of unreported cases $[3,28]$. It is therefore essential to control evasion and to implement enforcement strategies actively [35]. In this respect, dedicated action is needed; however, as Welsh and Farrington [36] state in their review of the costs and benefits of situational crime prevention, only little is known about the economic value of related strategies.

Table 1. Trends in local public transport companies in Germany.

\begin{tabular}{|c|c|c|c|c|c|}
\hline City & $\begin{array}{l}\text { Company } \\
\text { (Acronym) }\end{array}$ & $\begin{array}{l}\text { Free-Rider Quota a } \\
\text { in Percent (Trend) }\end{array}$ & $\begin{array}{c}\text { Income Loss }^{a} \\
\text { (In Million Euros) }\end{array}$ & Controls $^{b}$ & $\begin{array}{l}\text { Tightening of } \\
\text { Controls Planned }\end{array}$ \\
\hline Chemnitz & CVAG & 6.0 (up) & 1.4 & 1,3 & Yes \\
\hline Berlin & BVG & 4.0 (constant) & 20.0 & $1,2,3,4$ & No \\
\hline Oberhausen & Stoag & 4.0 (down) & n.s. & 2,3 & No \\
\hline Bonn & SWB & 3.9 (constant) & n.s. & $1,2,3$ & Yes \\
\hline
\end{tabular}


Table 1. Cont.

\begin{tabular}{|c|c|c|c|c|c|}
\hline City & $\begin{array}{l}\text { Company } \\
\text { (Acronym) }\end{array}$ & $\begin{array}{l}\text { Free-Rider Quota }{ }^{a} \\
\text { in Percent (Trend) }\end{array}$ & $\begin{array}{c}\text { Income Loss }^{a} \\
\text { (In Million Euros) }\end{array}$ & Controls $^{b}$ & $\begin{array}{c}\text { Tightening of } \\
\text { Controls Planned }\end{array}$ \\
\hline Kiel & KVG & 3.0 (constant) & 0.8 & 1,2 & No \\
\hline Stuttgart & SSB & 3.0 (constant) & 14.0 & $1,2,3$ & Yes \\
\hline Wiesbaden & ESWE & 3.0 (constant) & 1.0 & 2,3 & No \\
\hline Wuppertal & WSW mobil & 3.0 (constant) & 1.2 & 2,3 & Yes \\
\hline Augsburg & SWA & 2.5 (constant) & 1.4 & 1 & No \\
\hline Mönchengladbach & Möbus & 2.5 (constant) & 1.0 & 2 & Yes \\
\hline Freiburg & VAG/RVF & 2.4 (constant) & 1.5 & $1,2,3$ & No \\
\hline Düsseldorf & Rheinbahn & 2.0 (constant) & 4.0 & 2,3 & No \\
\hline Hannover & Üstra & 1.8 (down) & 2.4 & 1,2 & No \\
\hline Halle/Saale & Havag & 1.5 (constant) & 1.8 & 2,3 & No \\
\hline Leipzig & LVB & 1.5 (down) & 2.0 & 1,2 & No \\
\hline Dortmund & DSW21 & 1.4 (up) & 4.5 & 2,3 & Yes \\
\hline Krefeld & SWK & 1.0 (constant) & 0.5 & $1,2,3,4$ & No \\
\hline Nürnberg & VAG & 0.9 (down) & 1.0 & $1,2,4$ & No \\
\hline Bochum & Bogestra & 0.6 (constant) & $<1.0$ & $1,2,3,4$ & No \\
\hline Gelsenkirchen & Bogestra & 0.6 (constant) & $<1.0$ & $1,2,3,4$ & No \\
\hline
\end{tabular}

a Specification of local public transport companies (partial estimates; if range, highest value); ${ }^{\mathrm{b}} 1$ by uniformed staff, 2 by plain clothed staff, 3 large scale controls (partly supported by police); 4 entrance controls by bus drivers; n.s.: not specified. Source: Schlesiger [17].

From the transport companies' point of view, wrongdoing of all kinds and grades of severity have to be fought equally, as minor offences occur much more frequently and thus result in significant cumulative financial damage, while even a single severe crime can entail substantial losses. All forms of fare evasion or ticket fraud are more or less unacceptable as they undermine honest passengers' integrity and illegally take advantage of a service not paid for. Approaches and technologies designed to prevent free-riding are very different and also depend on whether it is believed that the local public transport system should be kept open or closed [2,37,38].

In an open access system, there are no ticket controls when entering a station or boarding a vehicle. Instead, local public transport companies usually conduct frequent ticket inspections with either uniformed or plain-clothed staff. Sometimes large-scale controls with police support are carried out at large hubs. In closed systems, access is controlled by staff (mostly bus drivers) selling and inspecting tickets [39]. In Berlin, the introduction of this system in 2004 resulted in a significant reduction of fare-dodgers on buses from $4.5 \%$ to $1.6 \%$. Passengers' acceptance was high and there were no operating problems or longer travel times [40]. However, an increase in critical incidents and violent conflicts was reported [41]. Aggressive behaviour among passengers, against staff in general and against ticket inspectors in particular, is a severe problem. However, by increasing the "human factor", i.e., the number of staff as well as co-operation with police and security staff, it is possible to reduce both aggressive behaviour and fare dodging significantly [2]. This is partly due to the increased probability of being punished [42] while there is also a trade-off between the probability and the magnitude of the fine [43]. Personal ticket inspections are critical situations which consist of complex processes that need to be taken seriously by corporate management in order to best reach the intended goals $[44,45]$.

An alternative to personal controls are physical or technical barriers like turnstiles, automatic gates or doors, etc. Depending on the type of ticket used, a distinction between mechanical and electronic systems can be made. In mechanical systems, the ticket has to be inserted into a card-reading device where it is checked, whereas electronic systems use contactless Radio-frequency identification (RFID) smartcards [46] which do not need physical contact with the facility (check-in/check-out). Using RFID 
technology has several advantages. Firstly, while these are still 'closed' systems, they can be designed like open ones (be in/be out), as there is basically no need for physical barriers like turnstiles. They thus combine the benefits of both systems, since even closed systems still need personal inspections as barriers can be surmounted $[2,39,47]$. Moreover, electronic systems are also very effective in terms of marketing, sales and ticketing, since they capture data which can then be used for transport planning and service adjustments as well as for statistics and performance measurements [48].

To conclude, it can be observed that despite growing literature about fare evasion and ticket forgery in public transport [4,42,44,49-52], there has been rather little research so far on this topic with practical relevance, particularly from an economic perspective [7].

\section{Method}

The name of the Delphi method refers to the ancient oracle of Delphi and is associated with predictions and forecasts. The first modern applications of the Delphi technique date back to the 1940s, where it was employed to predict the results of dog or horse races. Later, the method was developed further and used by the US-based RAND corporation for military purposes [53-55]. During the next decades, the broad acceptance of the method also led to further developments, different forms and areas of application as well as methodological discussions. While there is still no clear definition of the method, Häder [53] lists several characteristics and requirements which appear to be crucial for the definition of the classical method and are fulfilled in most applications, based on an extensive literature review: (1) the use of a formalised questionnaire; (2) an expert survey; (3) the anonymity of individual responses; (4) the determination of a statistical group response; (5) feedback to the participants about this group response; (6) (multiple) repetition(s) of the survey according to this scheme. However, there have been heated debates about variants and applications [56-60]. Indeed, perhaps a Delphi study should be conducted in order to reach a consensus on how to conduct a Delphi study. An attempt to develop a typology was made by Strauss and Zeigler [61], who stated there were three types of Delphi studies: numeric (aiming to specify a single or minimum range of numeric estimates or forecasts); policy (to define answers to current or anticipated policy problems); and historic (determining the issues which were causal for a certain decision in the past or alternatives to that decision). Despite a lack of consensus as to how to conduct a study, researchers are in agreement that the method can be employed in order to determine the opinion of a group of experts on a certain problem or phenomenon.

Consequently, the Delphi analysis has also been used quite frequently in the field of transport research, [62-67]. This study conducted a Delphi analysis on the subject of fare evasion and ticket forgery in public transport by sending out two rounds of surveys to experts in a representative number of public transport companies and transport associations in Austria, Germany and the German-speaking part of Switzerland.

At the beginning of the project, several general research questions (RQ) were developed which were then operationalised for the actual questionnaire:

- RQ1: What are the reasons and drivers of fare evasion and ticket forgery? What are the motives of people committing these offenses and what is the perspective of the general public?

- RQ2: How serious are the phenomena of fare evasion and ticket forgery for the transport companies and how will they develop in the future?

- RQ3: What are the most effective measures against fare evasion and ticket forgery? How can electronic ticketing contribute to the fight against these phenomena?

\subsection{Questionnaire Development}

On the basis of these research questions, a questionnaire (The questionnaire is available upon request) was developed which was not only intended to serve as an instrument to gather the experts' views, but also to ask them to put themselves in the position of free-riders and ticket forgers. With this change of perspectives, we intended to get a broader view and to encourage experts to consider as 
much information as possible. In addition to the multi-round approach of the Delphi method, it was hoped that this would encourage the development of cognitive processes and help respondents to give accurate answers.

The questionnaire consisted of 17 partly open, partly closed questions, some with sub-questions. 12 questions were related to free-riding, four to ticket fraud and one question was more general (see Figure 1). We addressed the experts' overall perception of the phenomena; its development over time; passengers' motives; measures and technologies to prevent and curtail free-riding and ticket fraud; penalties; estimated revenue losses; related legal regulations; the social aspects of ticket inspections; the acceptance of inspections by paying passengers; and whether using a transport service without paying is seen as trivial offence or as a serious crime. Before the questionnaires were sent out, the wording was discussed with an expert in qualitative research and a pre-test was performed. The research design stipulated two waves of surveys by email, followed by a third round in the form of a non-public internet forum. This was officially entitled the "transmission of results" to the experts, but it also gave them one more opportunity to actively comment on these results. As another incentive to review them, the results were first provided exclusively to the panel. The questionnaire was sent out as a Microsoft Word document which was tested for various versions of the program. This procedure was preferred to an online questionnaire as it was assumed that a file can be saved on a laptop or in printed form and the respondent does not necessarily need to be online when giving the answers. This was supposed to encourage more thoughtful, considered responses and made it possible to fill out the questionnaire not only in the office but also somewhere else. For the final round, an active internet connection was needed.

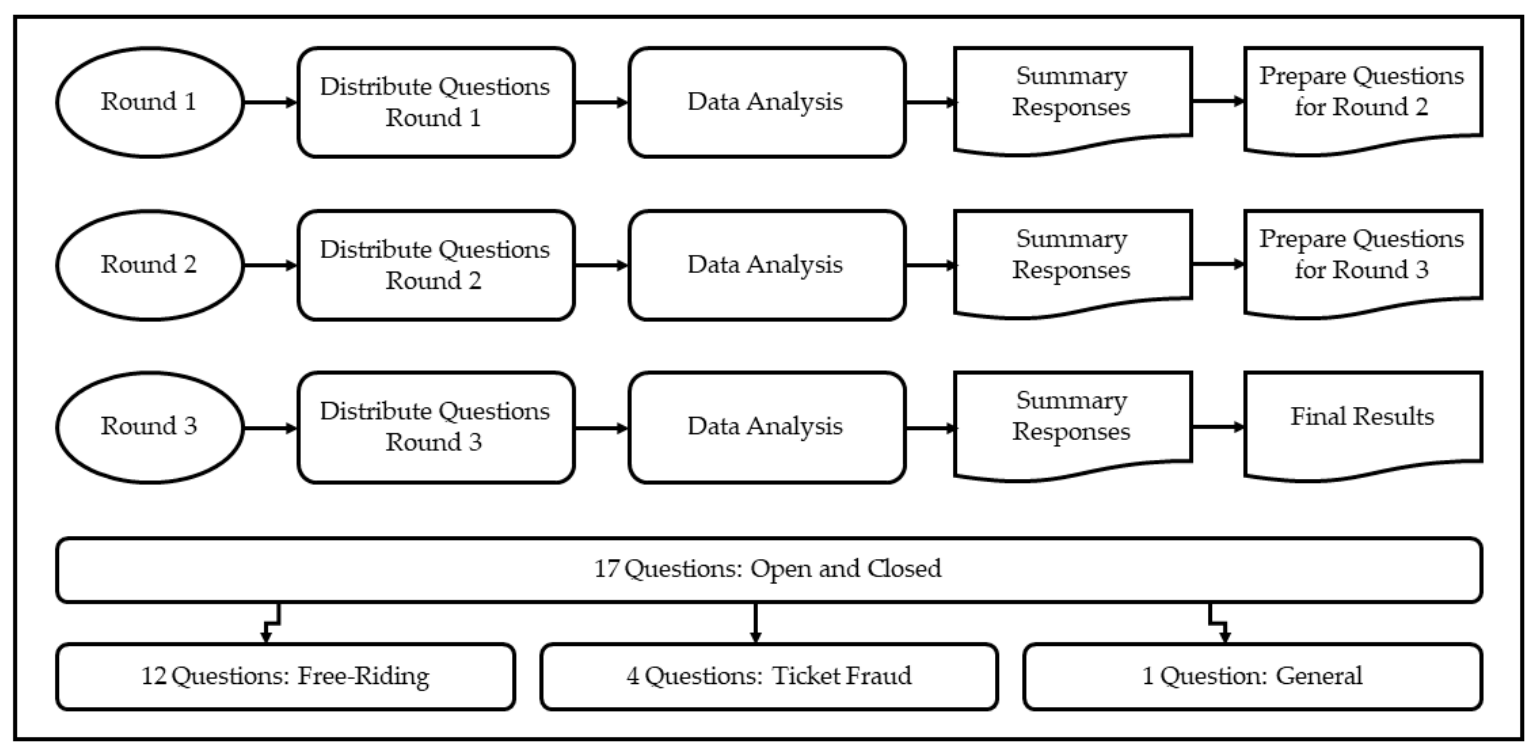

Figure 1. Delphi survey process.

To cover the German-speaking part of Europe in the best possible way, the panel was composed as follows. In principle, all persons involved or with some expertise in the field of research would suit the panel's requirements. In order to have some central criteria when selecting the experts, all major public transport companies and public transport associations (Verkehrsverbünde) in all cities with 100,000 or more inhabitants in Germany, Austria and the German-speaking part of Switzerland, as well in all federal state capitals, were contacted. The contacts were taken from a database compiled at the Institute for Transport and Logistics Management for the purpose of the study comprising all relevant public transport companies and transport associations in the respective region. In order to identify the expert in charge of the research topic, the companies were contacted by mail and/or telephone. 


\subsection{Delphi Study: Three Rounds Participation}

The first round started in April 2011. In total, a wave of 327 questionnaires were sent out by email accompanied by a cover letter signed by the head of the institute and the project manager asking for co-operation. The initial response in the ten-day period foreseen was rather low. After a reminder by mail, 23 questionnaires were returned. Another round of reminders where randomly chosen experts were approached by telephone and asked to participate in the study led to a total of 31 responses by the beginning of June 2011 (three from Switzerland, 10 from Austria and 18 from Germany), representing an overall response rate of about $10 \%$, which was considered acceptable. The returned answers were analysed and the 'average' answer was compiled to be sent out in round two. Answers to open questions deviating extremely from the group answer were listed separately. Finally, the questionnaire for the second wave was prepared. The group response was inserted below the questions where the respondents could state whether they agree completely, partly or not at all with the statement. If they did not agree completely, they were asked to explain why.

In the second round, all 31 experts who answered to the questionnaire of round one were contacted by mail in February 2012 and invited to participate again in round two. As contact details were available from the first wave, direct mails and telephone calls could be used to remind the respondents. In the end, 24 of the 31 initial experts completed and returned their questionnaires.

Moreover, the monitoring group also tried to involve new participants in the survey. Thus, 286 additional companies from the database were contacted at the end of February and the beginning of March 2012. By either sending mail or calling the experts directly, an additional 24 experts could be found. In total, $55(31+24)$ experts participated in at least one of the rounds, of which 14 were from Austrian companies, 32 German and 9 Swiss (Table 2).

Table 2. Participants of the respective rounds of the Delphi survey.

\begin{tabular}{cccccc}
\hline & $\begin{array}{c}\text { Participants in } \\
\text { Round 1 }\end{array}$ & $\begin{array}{c}\text { Participants in } \\
\text { Round 2 }\end{array}$ & $\begin{array}{c}\text { Participants in } \\
\text { Round 1 Only }\end{array}$ & $\begin{array}{c}\text { Participants in } \\
\text { Rounds 1 and 2 }\end{array}$ & $\begin{array}{c}\text { Total Participants } \\
\text { (Round 1 and/or } \\
\text { Round 2) }\end{array}$ \\
\hline $\mathrm{AT}^{\mathrm{a}}$ & 7 & 12 & 2 & 5 & 14 \\
$\mathrm{DE}^{\mathrm{b}}$ & 21 & 27 & 5 & 16 & 32 \\
$\mathrm{CH}^{\mathrm{c}}$ & 3 & 9 & 0 & 3 & 9 \\
Total & $\mathbf{3 1}$ & $\mathbf{4 8}$ & $\mathbf{7}$ & $\mathbf{2 4}$ & $\mathbf{5 5}$ \\
\hline
\end{tabular}

This approach might be criticised as classical Delphi studies would not extend the panel after round one. In principle, one core advantage of a Delphi study lies in the fact that by reconsidering the group answer in the following round, the experts will consider a broader basis of information. However, after some methodological discussions in the monitoring team and with experts in qualitative research, we decided to continue with the planned expansion of the group of experts, as we believed that:

(1) a new group would approach the study in an equally sincere/serious manner, as they would need to scrutinise the group answers from the previous round before being able to offer their own opinions;

(2) a broader review could open ways to new information which could then be reconsidered in round three and would strengthen the results;

(3) from a pragmatic and practical perspective, the disposition to take part in the survey would be greater for experts if the effort associated with it were reduced;

(4) the information gained would outweigh the limitations of having some new experts in the panel of the second round, particularly as the new group opinion could still be discussed- and if necessary revised-in round three. 
On average, $62.7 \%$ of the experts participating in round two agreed completely with the group answer, $21.5 \%$ agreed partly and only $4.3 \%$ not at all. The average non-response rate per question was only $4.9 \%$.

For the third round, an internet forum was prepared and a dedicated thread (discussion) was opened for each question, which included the "average" answer from round two. The forum was open to the participants of the first two rounds. Additionally, it was password-protected, with each expert being assigned a unique user-ID and password, thus ensuring that only persons who had already participated in the previous phases could post comments on the group answer for round two. A particularly beneficial characteristic of round three is that it was "adaptive", i.e., new postings could be posted in response to previous statements. Furthermore, since these still took place in an anonymous environment, it was possible for online discussions to emerge.

\section{Results}

In the following sections, the findings of the three rounds are presented and discussed.

\subsection{Characteristics and (Past and Future) Development of Free-Riding}

The experts emphasised that a clear distinction has to be made between people choosing deliberately to evade the fare and those who do not hold a valid ticket by mistake. The latter occurs, for instance, if somebody misunderstands the tariff and buys a wrong ticket for the journey. Free-riding is more common in central areas than in the periphery. However, dense city regions cannot be comprehensively covered by inspections and thus the frequency of controls is lower and the free-rider quota larger. Many people still regard fare dodging as a minor offence or lack the understanding that it is unlawful and disadvantageous for the general public. Many free-riders also disregard the fact that more free-riding results in higher ticket prices and hence the other passengers have to pay for the services they consume. Some passengers even like the challenge of not being trapped and simply seek the thrill.

There is consensus in the panel that more intensive controls help to reduce free-riding; the simple presence of ticket inspectors leads to a higher rate of compliance. In bus services, the obligation to board the vehicle at the front door where the driver inspects the ticket is seen as a very effective measure where there is experience of it. However, it can lead to delays in operations at peak times. A second problem is the rising propensity to violence and the resulting verbal or even physical attacks against staff.

Another means to reduce fare evasion and ticket forgery would be the broad introduction of electronic ticketing and a significant increase in its usage. This would also help to combat ticket forgery, which happens in both the small sense (e.g., the manipulation of a ticket's validity date) and on a large scale. In total, however, ticket forgery is nowhere near as common as free-riding.

In regard to the reasons for free-riding, the general economic situation is frequently blamed. However, tariffs are usually socially balanced, at least to a certain extent, thus negating any effects in this respect. Furthermore, if this were true, a higher rate of free-riding should be noticed in socio-economically disadvantaged areas, which is not the case. Thus, individual motives seem to be stronger than general economic ones, although obviously one's own personal economic situation and saving the fare is of course an important reason for not paying.

Regarding the future development of this phenomenon, about one half of the panel expects the rate of free-riding to rise in future, while most of the other experts believe it will remain constant and only very few foresee a fall.

\subsection{Reasons for and against Free-Riding from the Passengers' Perspective}

On the basis of the general statements above, the main reasons for committing fare evasion from the passengers' perspective lies in too lax controls and too low penalties (particularly in Germany, where the amount is determined by law at a rather low level of $€ 40$, compared with Vienna, where it 
is $€ 100)$. Due to the lack of controls, it may seem economically rational to save the cost of a ticket. Occasionally, people rate the fare as too high and regard the service as having a poor price-performance ratio, especially on short rides or when they perceive the service quality as being substandard. Passing on tickets (transmittable, poorly identified or personal) and small manipulations also save money. Again, as a result of complicated tariffs, people may buy a wrong ticket by mistake or simply forget to buy or validate their ticket. All in all, there are no clear groups of free-riders according to their income, social status or gender, etc. The main reasons why people decide against free-riding include the embarrassment of being fined, the damage to their image, a bad conscience, and the amount of the fines.

\subsection{Measures against Free-Riding}

Much can be done to prevent fare evasion. The most effective measure is to intensify inspections, to perform mass controls at large transfer stations or to cover a certain area where it is hard to bypass the inspections. A greater presence of staff already reduces the number of fare evaders. Penalties should be significantly raised, particularly in cases of deliberate manipulations, forgery and for repeat offenders. However, if they were too high, some would be unpayable, and many people would count on the inspectors' kindness. In most cases, the receipts will (or even must) not cover the costs, so, with the exception of a few urban areas, ticket inspection is not a source of profit. Therefore, some companies have outsourced this task to external contractors, causing an administrative burden as this requires a public EU-wide tender. A positive effect of ticket inspectors is the presence of staff which gives passengers an impression of service and security. Announcements of controls could help, but there is no agreement on that point.

On the technical side, there are several measures. For paper tickets, the paper used should have different security features like holograms, special imprints, barcodes, serial numbers, etc. From time to time, the kind/type of paper should be changed, as should the other security features. Once more, it was pointed out that electronic ticketing-not yet common in the surveyed area-would be effective but at the same time very costly due to large investments and the administrative burden this would involve. Barriers and particularly the front access to buses have positive effects but can also cause problems.

Rather simple measures which are expected to have a strong impact would be a more transparent and easily comprehensible tariff scheme, image campaigns, a rise in awareness and people's values and of course a better quality of service. All in all, a mixture of measures including intensified controls, transparent and simple tariffs as well as adequate penalties seems the best way to prevent free-riding.

\subsection{Strengths and Weaknesses of Different Control Systems}

- Mechanical checkpoints with turnstiles

Mechanical barriers yield a coverage and check rate of almost 100\%. Human errors are virtually impossible. On the downside, they require a completely closed system and huge investments; are space consuming; slow down passenger flows; can be a barrier for persons with reduced mobility; and can even be dangerous and fatal in case of emergencies when a station needs to be evacuated quickly. Additionally, staff need to be present at the stations to handle breakdowns and malfunctions and to monitor the proper use of the devices. Hence, the systems can only be used efficiently in urban areas for rail or underground services and not on buses or most trams.

\section{- Electronic systems}

Electronic systems-while costly as well-would be a good alternative in many respects. These systems work faster and can be contactless. Tickets are almost forgery-proof and the data collected electronically can be used for market research purposes. There is still a lack of experience in this area, particularly regarding information about free-riders. Barriers, devices and chipcards require 
substantial investments which are still not wholeheartedly accepted due to the fact that systems are not seen as fully developed. There is less fear of ticket fraud but more of system breakdowns and resulting revenue losses. It is also doubtful as to whether the systems are sufficiently transparent for passengers who want to be sure that they have the correct ticket with them. An advantage in this context is of course the electronic processing enabling the implementation of best price schemes.

- Controls by staff

At present, this is by far the most common option in the region covered by our research. Controls can be arranged and managed flexibly; staff represent service, security and the best means of deterrence. However, personnel costs are significant; hence, comprehensive controls are mostly not possible. Verbal insults or attacks by passengers have to be considered. Because of technical progress and a lack of time, inspectors may not detect all forged tickets. Of course, human control staff are also subject to inconsistent practices.

\subsection{Financial Damage (In Terms of Revenue Loss Measures against Free-Riding)}

In the first round, estimates of the financial damage resulting from fare evasion varied between $1.5 \%$ and $15 \%$ of revenues with a mean value of $4.1 \%$ and a median and modal value of $3 \%$. In the second round, the results were closer together. In Austria, the estimates lie between $1 \%$ and $10 \%$ (mean: 4.5\%); in Germany, between 1\% and 6\% (mean: 3\%); and in Switzerland, between 1\% and 15\% (mean: $5 \%$ ). Where the rate of pupils' transports is higher, there is a lower free-rider quota. Unfortunately, many companies did not respond despite the guarantee of anonymity.

\subsection{Effects of Electronic Ticketing}

Although in some places, such systems are already operational, experts lack experience with electronic ticketing systems. Accidental free-riding could be reduced as the validity of the ticket could be tested beforehand electronically and the amount deducted after the ride according to the distance travelled. An effect on deliberate free-riders is widely doubted. If such a system were to be cracked by hackers, the damage per case would be expected to be rather high. As the introduction is costly, it is crucial to calculate the benefits thoroughly beforehand.

For passengers, an electronic system offers various advantages. It offers pre- and post-price procedures together with best price schemes, and stolen cards can be immediately blocked and identified. Electronic tickets can be easily combined with front door access in buses where the driver can survey the proper use. Nevertheless, staff is needed, requiring special training and devices for ticket inspection purposes.

\subsection{Penalties and Processes of Control}

In Germany the amount is determined by law at $€ 40$ which is mostly regarded as too low by German experts. Still, no increases are foreseen and industry attempts in this respect have failed. In Austria, fines between $€ 55$ and $€ 138.20$ were reported, while in Switzerland, the penalties reported range between CHF 55 (€45.63) and CHF 150 (€124.45). The experts recommended a gradual increase for repeat offenders. In cases of ticket forgery, which is considered a crime, it is mandatory to file a charge. Sometimes this could also be helpful for multiple offences.

The behaviour of passengers is an important aspect to the processes of controlling and penalising. Verbal insults and even attacks against staff by illicit as well as paying passengers—many of them juvenile-seem to increase in urban regions. Controls accompanied by police are performed sometimes but are not frequent as there is often a lack of resources on the police side. Staff are frequently trained in de-escalation strategies and patrol in teams.

Goodwill in cases of "accidental" free-riding is at the inspector's discretion. Although some experts consider the legislation and judicature to be clear, others would like to see legal clarifications 
on the right of ticket inspectors to detain someone who fails to present a valid ticket in order to verify the person's identity and address.

\subsection{Announcement of Controls}

Announcing controls via the media (mostly the radio and internet) is rare and there are very diverging opinions on that point. The experts generally agreed that announcements should neither suggest that all people are free-riders nor help passengers evade the fare. If controls are announced, they also need to be conducted in order to stay credible. A raise of morale could be one effect. However, while people will buy tickets for lines where inspections are foreseen, the opposite may happen elsewhere. Consequently, not all inspections should be revealed; instead, it could be an option to publish controls and results afterwards. Announcements are not seen as advertisements for public transport or the service providers as the latter should focus on timetables, services and the positive environmental effects rather than on ticket inspections. Many experts consider announcements absurd and nonsense. The use of social networks where groups inform people about places, lines and vehicles where controls are ongoing should be prohibited by law.

\subsection{Illegal Controls by Unauthorised Persons}

The rather new phenomenon that people pretend to be authorised ticket inspectors is known to the experts but is very rare. As inspecting staff are usually known to the vehicle drivers, such attempts only occur in longer trains and on lines with a high proportion of tourists as well as in urban areas.

\subsection{The Paying Passengers' View}

Experts could rate on an 11 point Likert scale (ranging from 0 to 10) whether they think that paying passengers feel disturbed by controls (where 0 meant "strongly disturbed" and 10 "not at all disturbed"). Both rounds had quite similar results with an average of 7.7 for the first round $(n=29)$ and 7.5 for the second round $(n=44)$. This means that companies assume that passengers with valid tickets have quite a bit of understanding for controls but also feel disturbed to a small extent.

An identical scale was used in order to rate whether paying passengers regard inspections as legitimate (with 0 representing "completely legitimate" and 10 "not at all legitimate"). Again, the results were similar in both rounds one and two. In round one the mean value was $2.0(n=29)$, while in round two it was $0.9(n=44)$. This is a clear statement that experts think passengers who pay properly for their rides regard ticket controls as legitimate measures by transport service providers.

A third question about the passengers' view addressed the experts' opinions as to whether passengers regard fare evasion as a minor offence (value of 0 on the scale) or as a serious crime (value of 10). Here, the experts' assumptions about passengers' perceptions yielded a mean value of 3.8 for round one $(n=29)$ and 3.7 for round $2(n=44)$. Thus, experts think that passengers consider fare dodging as somewhat immoral but do not see it as a major crime.

\subsection{Characteristics and (Past and Future) Development of Ticket Fraud and Forgery}

The problem of ticket fraud (manipulations or forged tickets) — still small—is rather restricted to urban areas. Some experts see a rising trend; this view, however, is not shared by others. The manipulation of school, student and other regular season tickets is frequent in some parts of the region under research. Much effort is put into forgery-proof technologies but over the years, security features have also been faked. The only way to prevent this is by regularly changing the tickets' characteristics (which is of course easier for e-tickets).

For paper tickets, an increasing number of forgeries on original paper was reported by the experts but was questioned in the second round as experts stated the effort which has to be invested does not pay off. Again, frequent changes to ticket layouts, imprints, etc. could help, but in many cases, this is not practical. A complete backtracking of paper rolls is essential and inevitable. Falsifications and forgeries are becoming more professional; ticket inspectors are thus often unable to detect them in the 
short time they spend looking at the ticket if they do not use electronic checking devices. Furthermore, the photos on personalised tickets are often too small to immediately recognise if the person presenting the ticket is the same as the one on the photo. Another problem are online print-at-home-tickets, as their validity can only be checked using a barcode scanner. The financial damage caused by ticket forgery is marginal and negligible at present.

\subsection{Secure Electronic Ticketing}

In addition to what has already been said about e-ticketing, coding and security features are of particular importance. So far there has been little experience and hence also a lack of expertise on the subject. Most experts are sure that ticket forgery can be deterred significantly by electronic tickets. For inspection, an electronic check is inevitable, and a mere visual inspection is insufficient in this respect. Furthermore, passengers need to have the opportunity to check the ticket themselves in order to ensure the transparency of credits, transfers, validity, etc. At the same time, there is the fear that electronic systems will not be immune to criminal acts in the long run, either.

\subsection{Local Public Transport for Free}

One strategy could-in principle-immediately resolve the problem of free-riding and ticket fraud; namely, if local public transport was offered free of charge to everyone. The survey also raised this point eventually.

There is a general rejection of this concept. Where such approaches have been tested, they have failed to increase passenger volumes and the modal shift towards public transport to the desired extent. The experts deem it best if the user of a service also has to pay for it as there is a general belief that things offered free of charge have no value. Another problem could result in a higher rate of vandalism, soiling and littering.

In any case, such a system could work only if it was financed by the state, which would then automatically result in higher taxes. A general tax for public transport used for financing the system could be an option, which would have the advantage of a rise in passengers to a certain extent, a lower burden for the environment and a complete elimination of ticketing and sales and all the administrative processes associated with these. However, it might be difficult to define the border between local, regional and intercity services. From the companies' standpoint, service quality would suffer as there would be no incentive to maintain or improve it, to succeed in a market or to attract passengers. Hence, this approach would be highly unrealistic.

The matter remains a political question, but some experts proposed alternatives which they consider more effective; namely, lowering ticket prices to equal fuel prices or to significantly raise the service quality. Another approach could be to introduce a simple and clearly understandable fare concept applied equally in many regions and transport associations, which would reduce barriers that often deter persons who are not frequent users of local public transport.

\section{Conclusions}

The Delphi analysis provided a very detailed and differentiated view on two problems of local public transport companies-fare evasion and ticket fraud-which both threaten the revenue basis of these companies. Free-riding, of course, is by far the larger and more frequent problem but the manipulation, falsification and forgery of tickets also occur, even if they turn out to be of minor importance.

The best strategy to fight these offences is to intensify controls, ideally performed by ticket inspectors. This is in line with the findings of Bonfanti and Wagenknecht [3] stating that the human factor is crucial for reducing aggression and fare evasion. As a side effect, staff present at stations and in vehicles gives passengers a feeling of service and security, as also argued by Levinson and Odlyzko [2]. Controls of tickets are regarded as legitimate by paying passengers and the disturbance to them is limited. Raising service quality in general could also have positive effects on free-riding as 
sometimes people do not perceive a corresponding value for money. Other motives for fare evasion are protest, the thrill of not being caught and-most importantly - an attempt to save the fare.

Electronic ticketing, though quite costly, would probably have a good effect and would be also attractive to regular customers. In these cases, an international standard should be used, such as the "core application", which is the standard of the Association of German Transport Companies (VDV) or the "ITSO Specification", the UK technical standard for interoperable smart ticketing.

Passengers would prefer simple, understandable and transparent systems enabling integrated seamless travel. If-in the e-ticketing world-a separate ticket for every city or region is required, considerable potential for progress is lost. Instead of the well-known discussion and conflicts between individual (motorised) and public transport attempts, it would be much wiser to create gateways between the systems and modes. A smartcard could thus be an effective tool as it could open doors towards park and ride systems, car sharing, and taxi services, to name some quite obvious functions. There is also the important insight that it is not only the price that counts but the quality offered by the transport company which also matters. People are willing to pay a higher price if they perceive adequate value in exchange. To conclude, there should be a clear focus on an attractive overall system offering mobility services of high quality and in the way the customer needs them. This would also be the best way to establish a sustainable transport system which would serve the economic needs of the transport companies, the social aspect and the protection of the environment simultaneously.

This paper contributed to the body of knowledge in two ways: First, it provided a comprehensive and coherent overview about the public transport regarding fare evasion as well as ticket forgery, thereby not only presenting results and solutions with practical relevance, but also discussing the impacts on economic sustainability. Second, by identifying and defining the characteristics and drivers of fare evasion and ticket forgery and their implications, this paper provides a practical foundation to guide policy makers to shape the right policies for public transport in German, Austrian and Swiss societies.

More research in this field is needed. As this study is limited to Germany, Austria and Switzerland, a comparison with other countries would provide opportunities for further research, particularly from an economic perspective. These could include in-depth qualitative and quantitative studies on passengers' motives, strategies and behaviour, as well as an economic assessment of alternative measures to combat fare evasion and ticket fraud with a focus on associated costs and benefits.

Author Contributions: E.F. contributed to the manuscript by providing the initial concept and the research design. E.F. also performed the data collection and analysis and led the drafting of the manuscript. Both D.M.H. and E.F. contributed to and/or have approved the final manuscript.

Acknowledgments: This paper is part of the project "Fare Evasion and Ticket Forgery" conducted at the Institute for Transport and Logistics Management at WU Vienna. Elmar Fürst—who was head of this project—would like to thank all people engaged in the project's development, particularly all respondents for the valuable information as well as Julia Harant, Marita Bittner, Kerstin Stolz and Alexander Hodics who acted as project assistants during the several stages of the project for their efforts and support. Special thanks go to Renate Buber who cross-checked the questionnaire and for her valuable advice in designing the survey.

Conflicts of Interest: The authors declare no conflict of interest.

Ethical Clearance: No ethics approval was not required for this research.

\section{References}

1. Troncoso, R.; de Grange, L. Fare evasion in public transport: A time series approach. Transp. Rese. Part A Policy Pract. 2017, 100, 311-318. [CrossRef]

2. Levinson, D.; Odlyzko, A. Too expensive to meter: The influence of transaction costs in transportation and communication. Philos. Trans. R. Soc. A 2008, 366, 2033-2046. [CrossRef] [PubMed]

3. Bonfanti, G.; Wagenknecht, T. Human factors reduce aggression and fare evasion. Public Transp. Int. 2010, $59,28-32$.

4. Clarke, R.V.; Contre, S.; Petrossian, G. Deterrence and fare evasion: Results of a natural experiment. Secur. J. 2010, 23, 5-17. [CrossRef] 
5. Multisystems, Inc.; Mundle \& Associates, Inc.; Parsons Transportation Group, Inc. A Toolkit for Self-Service, Barrier-Free Fare Collection; Transportation Research Board: Washington, DC, USA, 2002.

6. Deibel, L.E. The introduction of European fare collection techniques in the us. J. Adv. Transp. 1981, 15, 55.

7. Barabino, B.; Salis, S.; Useli, B. A modified model to curb fare evasion and enforce compliance: Empirical evidence and implications. Transp. Res. Part A Policy Pract. 2013, 58, 29-39. [CrossRef]

8. Kennedy, C.; Miller, E.; Shalaby, A.; Maclean, H.; Coleman, J. The four pillars of sustainable urban transportation. Transp. Res. Part A Policy Pract. 2005, 25, 393-414. [CrossRef]

9. Herold, D.M.; Lee, K.-H. Carbon management in the logistics and transportation sector: An overview and new research directions. Carbon Manag. 2017, 8, 79-97. [CrossRef]

10. Cervero, R. Transit pricing research. Transportation 1990, 17, 117-139. [CrossRef]

11. Delbosc, A.; Currie, G. Why do people fare evade? A global shift in fare evasion research. Transp. Rev. 2018, 1-16. [CrossRef]

12. Yin, Z.; Jiang, A.X.; Johnson, M.; Tambe, M.; Kiekintveld, C.; Leyton-Brown, K.; Sandholm, T.; Sullivan, J. TRUSTS: Scheduling Randomized Patrols for Fare Inspection in Transit Systems Using Game Theory. AI Manag. 2012, 33, 59-72. [CrossRef]

13. Clarke, R.V. Fare evasion and automatic ticket collection on the London underground. Crime Prev. Stud. 1993, 1, 135-146.

14. Weidner, R.R. Target-hardening at a New York City subway station: Decreased fare evasion-At what price. Crime Prev. Stud. 1996, 6, 117-132.

15. Hauber, A.R. Fare evasion in a European perspective. Stud. Crime Prev. 1993, 2, 122-141.

16. Currie, G.; Reynolds, J. Evaluating pay-on-entry versus proof-of-payment ticketing in lightrail transit. Transp. Res. Rec. J. Transp. Res. Board 2016, 2540, 39-45. [CrossRef]

17. Lee, J.; Papas, D. All-door boarding in San Francisco, California. Transp. Res. Rec. J. Transp. Res. Board 2015, 2538, 65-75. [CrossRef]

18. Cools, M.; Fabbro, Y.; Bellemans, T. Identification of the determinants of fare evasion. Case Stud. Transp. Policy 2018, 6, 348-352. [CrossRef]

19. Barabino, B.; Salis, S.; Useli, B. What are the determinants in making people free riders in proof-of-payment transit systems? Evidence from Italy. Transp. Res. Part A Policy Pract. 2015, 80, 184-196. [CrossRef]

20. Correa, J.; Harks, T.; Kreuzen, V.J.C.; Matuschke, J. Fare evasion in transit networks. Oper. Res. 2017, 65, 165-183. [CrossRef]

21. Boyd, C.; Martini, C.; Rickard, J.; Russell, A. Fare evasion and non-compliance: A simple model. J. Transp. Econ. Policy 1989, 23, 189-197.

22. Guarda, P.; Galilea, P.; Handy, S.; Muñoz, J.C.; de Dios Ortúzar, J. Decreasing fare evasion without fines? A microeconomic analysis. Res. Transp. Econ. 2016, 59, 151-158. [CrossRef]

23. Barabino, B.; Salis, S.; Useli, B. Fare evasion in proof-of-payment transit systems: Deriving the optimum inspection level. Transp. Res. Part B Methodol. 2014, 70,1-17. [CrossRef]

24. Jiang, A.X.; Yin, Z.; Johnson, M.P.; Tambe, M.; Kiekintveld, C.; Leyton-Brown, K.; Sandholm, T. Towards optimal patrol strategies for fare inspection in transit systems. In Proceedings of the AAAI Spring Symposium: Game Theory for Security, Sustainability, and Health, Palo Alto, CA, USA, 26-28 March 2012.

25. Avenhaus, R. Applications of inspection games. Math. Model. Anal. 2004, 9, 179-192.

26. Kooreman, P. Fare evasion as a result of expected utility maximisation: Some empirical support. J. Transp. Econ. Policy 1993, 27, 69-74.

27. Eddy, D. Fare evasion-Is it a youth issue? Transit. Aust. 2010, 65, 1-7.

28. Bucciol, A.; Landini, F.; Piovesan, M. Unethical behavior in the field: Demographic characteristics and beliefs of the cheater. J. Econ. Behav. Organ. 2013, 93, 248-257. [CrossRef]

29. Witzel, V.T. Ticketfälscher: Farbkopierer War Gestern. Frankfurter Rundschau, 16 February 2010.

30. Ataman, F. Gefälschte Fahrscheine: Billige Tagestickets Schon am Frühen Morgen. Der Tagesspiegel, 1 March 2010.

31. Spiegel Online. Dreister Schwindel in Italien: Polizei Beschlagnahmt zwei Millionen Gefälschte Bahntickets. Available online: http:/ / www.spiegel.de/reise/aktuell/rom-italien-falsche-bahntickets-im-wert-von-28millionen-euro-a-839780.html (accessed on 22 August 2012). 
32. Wiener Linien. Mehr Fahrscheinkontrollen, Sinkende Schwarzfahrerquote. Available online: http:/ / www.wienerlinien.at/eportal/ep/contentView.do/contentTypeId/1001/channelId/-8615/ programId/22534/pageTypeId/9320/contentId/25239 (accessed on 22 August 2012).

33. Göweil, R. Mai Kostet Schwarzfahren 100 Euro: 60.000 Schwarzfahrer in Wien Ertappt: Zahlen für das Erste Quartal Zeigen Steigende Tendenz. Wiener Zeitung, 22 April 2012.

34. Meckel, M. Undercover-Einsatz: Nahverkehr I Bus- und Bahnbetreiber Erleiden hohe Einnahmeverluste Durch Schwarzfahrer. Nun Leisten die Städte Gegenwehr. WirtschaftsWoche, 16 April 2012, pp. 58-59.

35. Reddy, A.V.; Kuhls, J.; Lu, A. Measuring and controlling subway fare evasion: Improving safety and security at new york city transit authority. J. Transp. Res. Board 2011, 2216, 85-99. [CrossRef]

36. Welsh, B.C.; Farrington, D.P. Value for money? A review of the costs and benefits of situational crime prevention. Br. J. Criminol. 1999, 39, 345-368. [CrossRef]

37. Sasaki, Y. Optimal choices of fare collection systems for public transportations: Barrier versus barrier-free. Transp. Res. Part B Methodol. 2014, 60, 107-114. [CrossRef]

38. Lee, K.-H.; Herold, D.M. Cultural relevance in corporate sustainability management: A comparison between korea and japan. Asian J. Sustain. Soc. Responsib. 2016, 1, 1-21. [CrossRef]

39. Dauby, L.; Kovacs, Z. Fare evasion in light rail systems. In Proceedings of the Joint International Light Rail Conference: A World of Applications and Opportunities, St. Louis, MO, USA, 9-11 April 2007; pp. 230-246.

40. Müller, J.; Reinhold, T. Ein jahr vordereinstieg beim bus: Erfahrungsbericht aus sicht des betriebs und des marketings der berliner verkehrsbetriebe. Nahverkehr 2005, 23, 58-60.

41. Casdorff, S.; Maroldt, L. Ihre Meinung: Sollten Fahrgäste im Bus Wieder Hinten Einsteigen Dürfen? Der Tagesspiegel, 4 November 2008.

42. Killias, M.; Scheidegger, D.; Nordenson, P. The effects of increasing the certainty of punishment: A field experiment on public transportation. Eur. J. Criminol. 2009, 6, 387-400. [CrossRef]

43. Polinsky, A.M.; Shavell, S. The optimal tradeoff between the probability and magnitude of fines. Am. Econ. Rev. 1979, 69, 880-891.

44. Bijleveld, C. Fare dodging and the strong arm of the law. J. Exp. Criminol. 2007, 3, 183-199. [CrossRef]

45. Suquet, J.-B. Drawing the line: How inspectors enact deviant behaviors. J. Serv. Mark. 2010, 24, 468-475. [CrossRef]

46. Sadeghi, A.-R.; Visconti, I.; Wachsmann, C. User Privacy in Transport Systems Based on Rfid e-Tickets. In Proceedings of the PiLBA 08 Workshop-Privacy in Location Based Applications, Malaga, Spain, 9 October 2008.

47. Mayes, K.E.; Markantonakis, K.; Hancke, G. Transport ticketing security and fraud controls. Inf. Secur. Tech. Rep. 2009, 14, 87-95. [CrossRef]

48. Pelletier, M.-P.; Trépanier, M.; Morency, C. Smart card data use in public transit: A literature review. Transp. Res. Part C Emerg. Technol. 2011, 19, 557-568. [CrossRef]

49. Van Andel, H. Crime prevention that works: The care of public transport in the Netherlands. Br. J. Criminol. 1989, 29, 47-56. [CrossRef]

50. Hauber, A.; Hofstra, B.; Toornvliet, L.; Zandbergen, A. Some new forms of functional social control in the netherlands and their effects. Br. J. Criminol. 1996, 36, 199-219. [CrossRef]

51. Smith, M.J.; Clarke, R.V. Crime and public transport. Crime Justice Rev. Res 2000, 27, 169-233. [CrossRef]

52. Herold, D.M.; Lee, K.-H. Carbon disclosure strategies in the global logistics industry: Similarities and differences in carbon measurement and reporting. In Pathways to a Sustainable Economy; Springer: Cham, Switzerland, 2018; pp. 87-101.

53. Dobrovnik, M.; Herold, D.M.; Fürst, E.; Kummer, S. Blockchain for and in Logistics: What to Adopt and Where to Start. Logistics 2018, 2, 18. [CrossRef]

54. Dalkey, N.C. The Delphi Method: An Experimental Study of Group Opinion; RAND Corporation: Santa Monica, CA, USA, 1969.

55. Brown, B.; Cochran, S.W.; Dalkey, N.C. The Delphi Method, II: Structure of Experiments; RAND Corporation: Santa Monica, CA, USA, 1969.

56. Linstone, H.A.; Turoff, M. The Delphi Method: Techniques and Applications; Addison-Wesley: Reading, MA, USA, 1975. 
57. Seeger, T. Die delphi-methode-Expertenbefragungen zwischen prognose und gruppenmeinungsbildungsprozessen. In Überprüft am Beispiel von Delphi-Befragungen im Gegenstandsbereich Information und Dokumentation; Hochschul-Verlag: Freiburg, Germany, 1979.

58. Häder, M.; Häder, S. Die Grundlagen der Delphi-Methode; Ein literaturbericht: Mannheim, Germany, 1994.

59. Herold, D.M. Has Carbon Disclosure Become More Transparent in the Global Logistics Industry? An Investigation of Corporate Carbon Disclosure Strategies Between 2010 and 2015. Logistics 2018, 2, 13. [CrossRef]

60. Häder, M.; Häder, S. Die delphi-methode als gegenstand methodischer forschungen. In Die Delphi-Technik in den Sozialwissenschaften. Methodische Forschungen und Innovative Anwendungen; Häder, M., Häder, S., Eds.; ZUMA-Publikationen: Wiesbaden, Germany, 2000; pp. 11-31.

61. Strauss, H.J.; Zeigler, L.H. The delphi technique and its uses in social science research. J. Creat. Behav. 1975, 9, 253-259. [CrossRef]

62. English, J.M.; Kernan, G.L. The prediction of air travel and aircraft technology to the year 2000 using the delphi method. Transp. Res. 1976, 10, 1-8. [CrossRef]

63. Faller, P.; Bacher, R.; Oblak, H. Die Zukunftschancen der Eisenbahn: Delphi-Studie: Gesamtbericht; Inst. für Transportwirtschaft d. Wirtschaftsuniv: Vienna, Austria, 1990.

64. Höjer, M. Transport telematics in urban systems-A backcasting delphi study. Transp. Res. Part D Transp. Environ. 1998, 3, 445-463. [CrossRef]

65. Shiftan, Y.; Kaplan, S.; Hakkert, S. Scenario building as a tool for planning a sustainable transportation system. Transp. Res. Part D Transp. Environ. 2003, 8, 323-340. [CrossRef]

66. Mason, K.J.; Alamdari, F. Eu network carriers, low cost carriers and consumer behaviour: A delphi study of future trends. J. Air Transp. Manag. 2007, 13, 299-310. [CrossRef]

67. Von der Gracht, H.A.; Darkow, I.-L. Scenarios for the logistics services industry: A delphi-based analysis for 2025. Int. J. Prod. Econ. 2010, 127, 46-59. [CrossRef]

(C) 2018 by the authors. Licensee MDPI, Basel, Switzerland. This article is an open access article distributed under the terms and conditions of the Creative Commons Attribution (CC BY) license (http://creativecommons.org/licenses/by/4.0/). 